\title{
Bivalve hatchery technology: The current situation for the Pacific oyster Crassostrea gigas and the scallop Pecten maximus in France
}

\author{
René Robert ${ }^{(a *)}$, André Gérard ${ }^{(b)}$ \\ (a) Laboratoire de physiologie des invertébrés manins, Ifremer, Centre de Brest, B.P. 70, 29280 Plouzané, France. \\ (b) Laboratoire génétique, aquaculture et pathologie, Ifremer, Ronces-Les-Bains, B.P. 133, 17390 La-Tremblade, France.
}

Received October 23, 1998; accepted January 11, 1999.

\begin{abstract}
The French oyster farming industry relies almost exclusively on juveniles collected from the nalural environment; the supply of spat produced by hatcheries is low, about $10 \%$ of the industry's requirements. Development through selective breeding of oyster stocks which are better suited for aquaculture purposes, is likely to reverse this tendency since only hatcheries will be able to supply such animals. Scallop farming, which at present is poorly developed in France, relies exclusively on hatchery produced spat. Although hatchery technology is constantly being improved, significant production problems remain which must be solved before hatcheries become a major supplier of juveniles for the industry. This paper describes the present state of hatchery technology in France based on experimental results obtained with the great scallop Pecten maximus and the Pacific oyster Crassostrea gigas, over the past ten years. Compared to the great scallop, the Pacific oyster has higher D larva yields $(60 \%$ for $C$. gigas vs. $30 \%$ for $P$. maximus $)$ and a faster larval growth rate $\left(10 \mu \mathrm{m} \cdot \mathrm{d}^{-1}\right.$ for $C$. gigas vs. $5 \mu \mathrm{m} \cdot \mathrm{d}^{-1}$ for $P$. maximus $)$. However, Pacific oysters have a greater heterogeneity during larval development and higher mortality rates (40\% for $C$. gigas vs. $25 \%$ for $P$. maximus) which produce lower overall yields of pediveliger larvae ready-to-set for Pacific oysters (15\%) compared to the great scallop (30\%). Development of continuous larval and post-larval culture methods along with development of continuous phytoplankton technology offers one of the most promising methods to improve molluscan hatchery techniques. (C) Ifremer/Cnrs/Inra/Ird/Cemagref/Elsevier, Paris
\end{abstract}

Molluscan rearing / hatchery / Crassostrea gigas / Pecten maximus

Résumé - Écloserie de mollusques en France : situation actuelle de l'huître creuse Crassostrea gigas et de la coquille SaintJacques Pecten maximus. En France, l'ostréiculture repose essentiellement sur le captage de juvéniles du milieu naturel, la part du naissain provenant d'écloserie étant environ de $10 \%$ en 1998. Cependant, l'introduction de souches d'huîtres plus adaptées à l'élevage, issues des programmes de sélection, devrait accentuer cette tendance car seules les écloseries seront capables de produire à terme ce type de produit. Par ailleurs, la pectiniculture française en 1998 dépend intégralement du naissain d'écloserie. Si les techniques d'écloserie sont en constante amélioration, la maîtrise de l'ensemble des processus est loin d'être absolue à ce jour. Cette étape est cependant indispensable pour disposer d'outils fiables de production. Cette étude présente une synthèse de travaux expérimentaux conduits sur la coquille Saint-Jacques Pecten maximus et sur l'huîtrc Crassostrea gigas, depuis 1984 en écloserie. Comparée à la coquille Saint-Jacques, l'huître présente des taux de formation de larves D (60\% chez C. gigas contre $30 \%$ chez $P$. maximus) et des taux de croissance larvaire $\left(10 \mu \mathrm{m} \cdot \mathrm{j}^{-1}\right.$ chez $C$. gigas contre $5 \mu \mathrm{m} \cdot \mathrm{j}^{-1} \mathrm{chez} P$, maximus $)$ plus élevés. Néanmoins, une plus forte hétérogénéité de la croissance et une mortalité larvaire plus importante sont relevées chez l'huître (40\% chez C. gigas contre $25 \%$ chez P. maximus) conduisant à de moindres rendements d'élevage larvaire (15\% chez $C$. gigas contre $30 \%$ chez $P$. maximus). Les élevages larvaires en circuit ouvert et les productions phytoplanctoniques en continu constituent deux voies particulièrement prometteuses pour améliorer les techniques d'écloserie de bivalves. (C) Ifremer/Cnrs/Inra/Ird/Cemagref/Elsevier, Paris

\section{Élevage de bivalve / écloserie / Crassostrea gigas / Pecten maximus}

* Corresponding author, e-mail: rrobert @ifremer.fr 


\section{INTRODUCTION}

Producing approximately 150000 toysters annually, France is the third largest oyster producer in the world and the largest European producer. Juveniles for the French industry are obtained mainly by collection from the natural environment (the Marennes-Oléron and Arcachon basins). In peak spawning periods when high numbers of spat are collected (i.e. when large numbers of spat collectors are exposed), the number of spat gathered is estimated to be about 17 billions, measured $15 \mathrm{~d}$ to 1 month after settlement. During their first year, mortality, due essentially to predation and overcrowding, is high at about $80 \%$. Hence, Pacific oyster breeding centres in France can produce about 3.5 billion spal weighing $2 \mathrm{~g}$ each per year. Under normal conditions during the 2 nd and 3 rd years, mortality levels are about 15 and $5 \%$, respectively. Hence, production potential is in the vicinity of 180000 toysters ( 2.8 billion individuals $\times 65 \mathrm{~g}$ ) and natural spatfall should theoretically supply this industrial demand.

However, recruitment can vary considerably from year to year, mainly due to differences in water temperature. In addition, the number of spat collectors (cultch) that are deployed will affect the tolal annount of spat collected. These two factors can produce a variability in the total amount of spat collected between 1 and 10 in the Arcachon basin and between 1 and 35 in the Marennes-Oléron basin from year to year.

Further, the large number of tourists, with accompanying development of coastal leisure activities, increases the fragility of these spat-producing areas. Collection of Crassostrea gigas spat was non-existent in the Arcachon basin over a period of live consecutive years due to the presence of anti-fouling paints containing tri-butyl tin which seriously affected the French shellfish farming industry [15].

The existence of the six French bivalve hatcheries has been precarious under these circumstances and they have experienced great difficulties adapting to the variable supply of spat from the natural environment. Hatcheries have been regarded as a 'safety net' for the industry and only hatcheries belonging to integrated companies (companies that produce market sized oysters) have been able to survive. However, due to adaptation of remote setting techniques, the role of hatcheries in supplying juveniles has been increasing (10-15\% of national demand). Development of broodstock produced through breeding programmes, that is more suited to aquaculture purposes (e.g. production of triploid spat) should assist in furthering development of hatcheries. The role of hatcheries should become more important to the industry in future years.

Two research groups stimulated present day oyster culture technology using hatchery methods with models for hard clams Mercenaria mercenaria and the eastern oyster Crassostrea virginica [19], and for the European oyster Ostrea edulis [32]. Since these previous investigations, work has intensified on these spe- cies [11] or on other commercially valuable bivalves (e.g. $[4,31]$ ).

Development of scallop culture technology is more recent, dating from initial experimental work in the 1980s [14]. Until then, landings of Pecten maximus were managed by classical stock assessment methods and quotas from traditional fisheries. The crash of the exploited scallop stocks in France (15000-25000 t during the 1970 s to $5000-6000 \mathrm{t}$ in 1985) led to the implementation of a restocking programme [7]. After a number of unsuccessful attempts at collecting wild spat from the bay of Brest, compounded with difficulties in obtaining juveniles from Scotland and Ireland, it became evident that it was necessary to produce juveniles in hatcheries [8]. At present, there is one commercial halchery producing greal scallop juveniles in France which was established through the combined efforts of scientists and professionals in the aquaculture industry.

\section{HATCHERY TECHNIQUES}

There are four distinct phases in the operation of a bivalve hatchery: broodstock conditioning, larval production, spat production and the production of phytoplankton. Regardless of the techniques used in each of these units, a sine qua non condition must be met: the biological quality of the seawater. These early stages in a bivalve's life history are particularly sensitive to anthropogenic factors [15]. A hatchery should be located in an area removed from both urban development and potential polluting sources (agricultural, industrial, port facilities, etc.). To date, hatcheries have usually been built in relatively isolated coastal areas. An alternative to building a hatchery in an isolated area is to use saline ground water (seawater naturally filtered through sand) since this water is often rich in nutrients and can be used in large-scale phytoplankton production [2] and/or larval rearing after treatment. mostly to decrease levels of iron and manganese. This latter technology has been used mostly in the Vendée and Charentes-Maritimes regions.

\section{BROODSTOCK CONDITIONING UNIT}

Techniques used for oyster culture have in fact changed very little since pioneering works $[19,32]$ and they have been adapted for scallop culture. Basically these techniques consist of collecting animals at various stages of sexual maturity from nature and placing them in tanks filled with temperature controlled seawater $\left(15 \pm 1^{\circ} \mathrm{C}\right.$ for scallops, $20 \pm 1^{\circ} \mathrm{C}$ for oysters) enriched with phytoplankton. Water is supplied either via a continuous flow-through system (scallop or oyster) or by a partial or complete recirculating system with water being replaced on a daily basis (oyster). For scallops, the bottom of conditioning tanks is covered with coarse sand which has a dual role: it allows the 
scallops to burrow into a substrate and it acts as a filter purifying the water which is returned to the tank via airlifts. A continuous supply of a phytoplankton algae mixture is provided to feed the broodstock. This mixture (PTCS) is composed of 1/5 vol. Pavlova lutheri, $1 / 5$ vol. Isochrysis aff. galbana, 1/5 vol. Chaetoceros calcitrans and 2/5 vol. Skeletonema costatum. Twenty litres of this mixture are provided daily to each tank, which represents about 10 billion cells per individual animal. This is not the true physiological requirement of the great scallop since a portion of this food is removed as a result of the continuous input of seawater or it becomes trapped in the sediment.

The minimal nutritional requirements for Pacific oysters, $C$. gigas, seem to be quite different from those of the great scallop. Studies have been undertaken to assess these differences in terms of both the quantity and quality of phytoplankton. Most hatcheries feed their broodstock with Skeletonema costatum and/or Tetraselmis suecica at about 2 billion cells per individual per day.

A 14-h daylight photoperiod is usually used in conditioning $P$. maximus [9] but the influence of this factor on conditioning $C$. gigas is unknown.

A simple method is used to determine whether a scallop is sexually mature and ready to spawn? When removed from water, the valves of the great scallop open widely and one can assess the state of the gonad visually. Conversely, an oyster out of the water closes its two valves and, the level of maturation of a given batch of oysters must be evaluated by sacrificing a few animals randomly and sampling the gonad. Nondestructive techniques (biopsy) to determine the state of gonadal maturity in oysters are currently being developed but to date, they have not proven to be reliable.

The exact period of time required for conditioning broodstock has not been determined. For the two species examined here, it is about 2 months but it will vary depending on the initial stage of gametogenesis and/or the level of reserves which have been stored in the animals when conditioning begins. Temperature is also important in establishing the duration of the conditioning period $[20,22]$. For both these species, the conditioning techniques do not permit the development of viable autumn spawnings (September-October). Studies are currently in progress to explain this phenomenon and overcome this problem.

\section{SPAWNING}

When artificial spawning is undertaken, mature animals are placed in spawning tanks. Spawning is triggered by thermal shock, attained by progressively increasing the seawater temperature from 15 to 20 $25^{\circ} \mathrm{C}$. P. maximus release male or female gametes indiscriminately (true hermaphrodites); however, initial spawns are generally males. Gametes are not released all at once but over a series of emissions (white for the spermatozoa, orange-coloured for the oocytes). To avoid self-fertilization, the animal is placed, at 5-10-min intervals, in a series of beakers until it begins to release gametes of the opposite sex. By microscopic examination, batches of spermatozoa exhibiting low mobility can be discarded as well as batches of burst oocytes. Other than for these microscopic methods, there are no other dependable methods to determine good or poor quality spermatozoa or oocytes (Percoll gradient [12] or lipid levels [17]). Eggs are counted with a profile projector or under a microscope and 10 to 30 million oocytes are fertilized with a suspension of spermatozoa at a dilution of 10 to $20 \mathrm{~mL} \cdot \mathrm{L}^{-\mathrm{P}}$. Fertilization is undertaken in 5-L beakers and observations are made 0.5 to $1 \mathrm{~h}$ later to insure fertilization is progressing normally.

Spawning of $C$. gigas can be undertaken in a similar manner; however, it is easier since the sexes are separate. Another viable method for obtaining ripe eggs and sperm from oysters is by stripping [1]; however, in this method, the oyster is sacrificed. It is not possible to use this technique with $P$. maximus since passage of the oocytes through the oviduct is necessary to reactivate meiosis [33].

\section{LARVAL REARING}

\subsection{Pecten maximus}

Results reported here were obtained at the experimental hatchery of Argenton over the last 5 to 13 years.

Half to one hour after fertilization, the embryos of P. maximus are placed in 450-L cylindrical conicalbased tanks at a concentration of 70 embryos $\cdot \mathrm{mL}^{-1}$. D stage larvae (the first larval stage) appeared $48 \mathrm{~h}$ after fertilization. The yield of D larvae per female usually ranged from 10 to $60 \%$ of fertilized eggs, a mean of $28.5 \%$ (standard error $=2.1 \%$ ). For conditioned adults, this high variability between individuals has been clearly demonstrated as well as a lack of correlation between the number of oocytes released and the yield of D larvae [18]. The percentage of aberrant larvae was low, between 0 and $25 \%$, a mean of $7.5 \%$ (standard error $=0.9 \%$ ).

The $\mathrm{D}$ larvae are pooled and placed in 450-L tanks, at a concentration of 7 to 10 larvae $\mathrm{mL}^{-1}$. Rearing systems currently used in France are closed systems and the seawater is completely renewed every 2 to $3 \mathrm{~d}$. A flow-through rearing system has been developed by a Scottish hatchery, although to date, results remain inconclusive [35]. Larger rearing volumes can be used for this species, as $45-\mathrm{m}^{3}$ tanks have been adopted for the rearing of the Japanese species Patinopecten yessoensis [25]. The pelagic phase lasts 3 to 5 weeks (mean $=25 \mathrm{~d}$, range $18-32 \mathrm{~d}$ ) at a temperature of $18{ }^{\circ} \mathrm{C}$ and a feeding rate of 60000 phytoplanktonic cells $\cdot \mathrm{mL}^{-1}$. Mean growth rates were 3-6 $\mu \mathrm{m}$ per day 


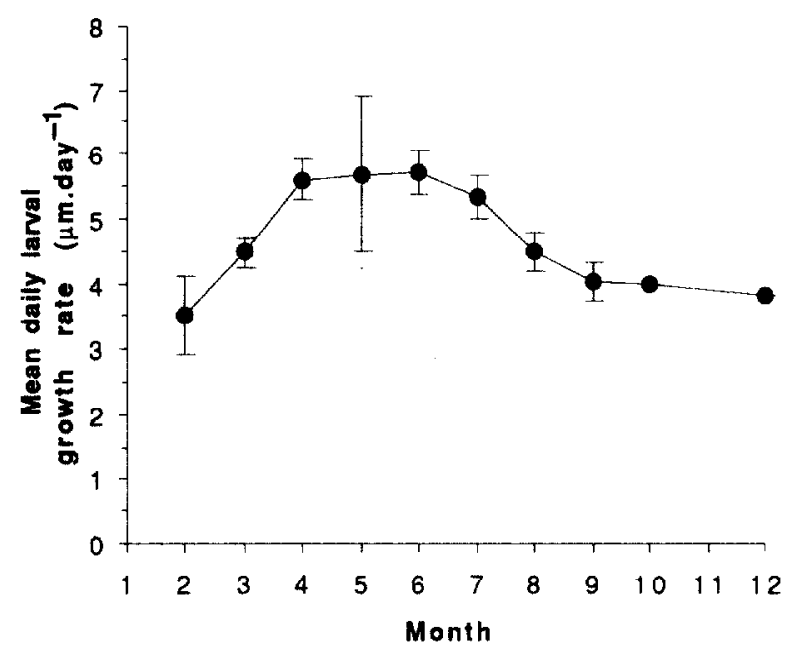

Figure 1. Variation in mean daily growth rates ( \pm standard deviation) of Pecten maximus larvac raised under standard rearing conditions (larval concentrations, temperature, food, etc.) throughout the ycar at the Argenton experimental hatchery (data were collected and pooled from 1992 to 1997). 1, January; 2, February; etc.

(range 2.5 to $8 \mu \mathrm{m} \cdot \mathrm{day}^{-1}$ ) and a distinct seasonal influence was noted (figure 1). Optimum growth rates occurred during the months of April to July and minimum rates in winter, December and February.

Yields of larvae ready-to-set (number of D larvae initially/number of larvae exceeding $212 \mu \mathrm{m}$ ) were variable, ranging from $15-50 \%$ (figure 2). The mean yield was about $28.6 \%$ (standard error $=1.4 \%$ ) for the period 1984-1997. The evolution of mean larval growth rate (figure 1) and yield of larvae ready to set (figure 2) are roughly similar throughout the year except for September and October. The seasonal difference in growth rate and yield may be due to initial egg quality which leads to higher larval survival rates.

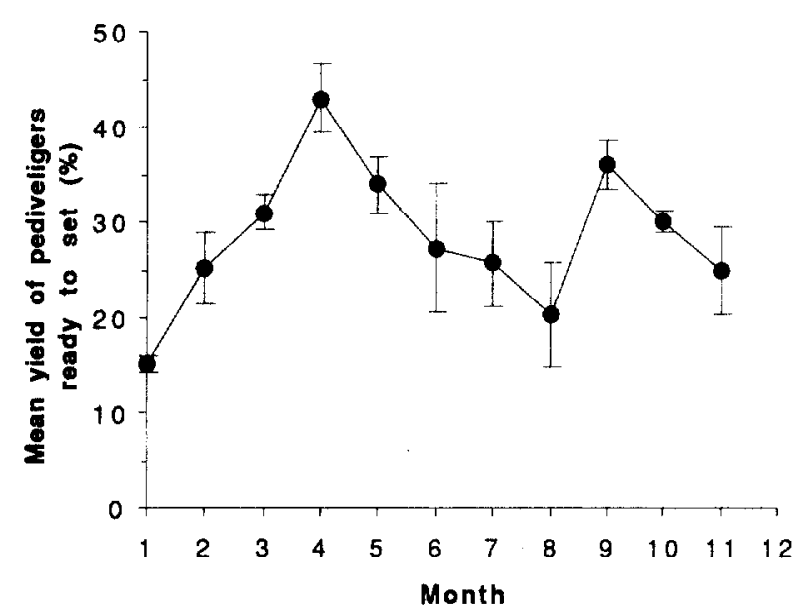

Figure 2. Variation in mean yicld ( \pm standard deviation) of Pecten maximus laryae raised under standard rearing conditions at the Argenton experimental hatchery (data were collected and pooled from 1992 to 1997). 1, January; 2, February; etc.
Indeed, during the autumn, broodstock was usually obtained directly from the natural environment. To date, various attempts to attain a good gonadal condition in autumn have been unsatisfactory. Maturation quality of individuals collected in situ in autumn is variable from year to year which leads to a high degree of variability between batches of larvae. The unpredictable nature of these autumnal yields would appear to be widespread in this species.

Larval growth rates for $P$. maximus are low but growth is relatively uniform. Little difference was noted between batches of larvae graded regularly and those subjected to one final sieving. Removal of larvae by sieving eliminates dead larvae and those with poor growth rates. Under normal conditions, mean larval mortality for the period from 1992-1997 was in the order of $25 \%$ (standard error $=2.7 \%$; range 1.5 to $55 \%$ ). The periods when the best results (in terms of growth and survival) were obtained were March-April and June-July. Generally, most larval production in the commercial hatchery at Le-Tinduff occurred during these periods.

\subsection{Crassostrea gigas}

Results reported here were obtained from 19921996 at the experimental hatchery in La-Tremblade. Larvae of the Pacific oysters were usually collected $24 \mathrm{~h}$ after fertilization at which time the yield of D larvae was much greater than those for $P$. maximus. The mean yield of $D$ larvae of fertilized eggs from 47 strippings was $59.2 \%$ (standard error $=3.2 \%$ ). Statistical analysis of data reported in figure 3 shows that results obtained throughout the year were not significantly different due to the high level of variability between batches of larvae. The level of anomalies for

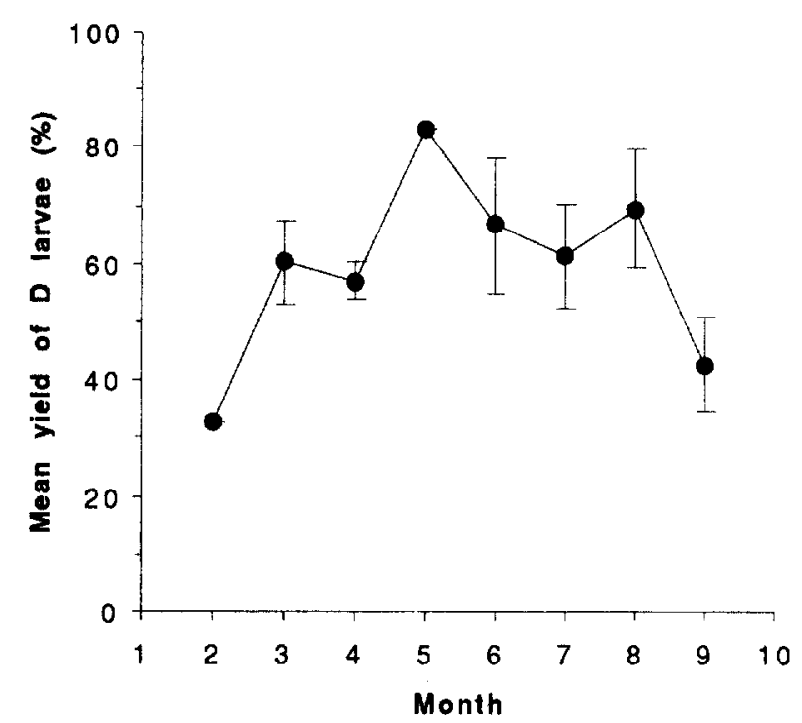

Figure 3. Variation in mean monthly yield ( \pm standard deviation) of Crassostrea gigas larvae obtained at the La-Tremblade experimental hatchery from February (2) to September (9) for pooled data from 1992 to 1996. 
the same data set was low, about $3.90 \%$ (standard error $=0.70 \%$; range $0-15 \%$ ).

The most frequently used method to raise oyster larvae uses a closed system. Two different techniques can be used in closed systems which can be called either the European or American system. The first method uses rearing volumes of $2-5 \mathrm{~m}^{3}$ and initial larval densities ranging from 5-10 larvae $\mathrm{mL}^{-1}$. The second method uses volumes of $45 \mathrm{~m}^{3}$ and initial larval densities of 1 larva $\mathrm{mL}^{-1}$. Water is renewed every $2-4 \mathrm{~d}$ with possible partial renewal on some days.

A new rearing technique has been developed recently in an English hatchery using a flow-through system. Rearing volumes are low $(200 \mathrm{~L})$ but initial larval densities are high at about 800 larvae $\mathrm{mL}^{-1}$. Throughout the rearing period, the larvae are provided with fresh seawater and phytoplankton. The tank's overflow-system is equipped with a filter which prevents loss of larvae. Selective larval grading is carried out during the rearing period which allows collection of 70 to 100 eyespot larvae $\mathrm{mL}^{-1}$ in $12-18 \mathrm{~d}$ at a temperature of $28^{\circ} \mathrm{C}$. Using traditional rearing techniques (closed systems), metamorphosis begins when larval densities are in the order of $1-2$ larvae $\cdot \mathrm{mL}^{-1}$, which is about fifty times less than the density observed in the flow-through system. The number of larvae obtained with this latter method is similar to that obtained using 10 and $20 \mathrm{~m}^{3}$ with the traditional rearing system. The flow-through system is one of the most promising methods of improving larval rearing techniques.

Regardless of the methodology used and apart from disease prevention, the two major environmental parameters that are controlled during larval rearing are temperature and amount of food. Rearing temperature varies considerably between hatcheries. Some hatcheries use a temperature as high as $28^{\circ} \mathrm{C}$ thus producing rapid larval growth and early metamorphosis. Under traditional rearing techniques, metamorphosis can occur as early as the 14th day at least for part of the larval population. The potential danger in using such high rearing temperatures is the risk of bacterial proliferation which can be detrimental to larvae. Another problem may be the selection of larvae (and juveniles) that are adapted to high temperatures. Other hatcheries use temperatures of $22-24^{\circ} \mathrm{C}$ which is approximately the mean seawater temperature at spat collection sites during the oyster's natural reproductive period. The higher the temperature, the greater the nutritional needs of the animal. Hence the quantity of phytoplankton provided in a closed system ranges from $50000-$ 150000 cells $\cdot \mathrm{mL}^{-1}$.

Nutritional needs of $C$. gigas are higher than those of $P$. maximus [26]. This can be seen by examination of growth requirements of larvae during a similar rearing period of approximately 3 weeks. Growth requirements are the difference between initial size of the larvae and the size they reached at metamorphosis. Thus for the great scallop, metamorphosis occurs when the larvae attain a length of $220-250 \mu \mathrm{m}$. As initial larval length was $100 \mu \mathrm{m}$, the growth coefficient during the larval period was in the order of 2.5 for this species. For the Pacific oyster, metamorphosis occurs when the larvae are approximately $320-350 \mu \mathrm{m}$ and initial larval length was $70 \mu \mathrm{m}$. The growth coefficient for Pacific oysters was 4.5-5. Pacific oyster larvae have growth requirements which are twice as high as those of the scallop. Supposing that the initial larval reserves for both species are quantitatively similar, it follows that oyster larvae deprived of food die within 6-14 d [16] whereas the mortality of scallop larvae reaches $40 \%$ after $20 \mathrm{~d}$ without food [26]. Oyster larvae rapidly exhaust their reserves indicating a higher metabolic rate and consequently greater nutritional needs.

Rearing and production strategies for Pacific oysters differ at commercial hatcheries and hence, it is difficult to obtain growth and larval yield data for long periods of time that are typical of the entire hatchery industry. Data given below are from experiments carried out from 1992-1996 at the experimental hatchery at La-Tremblade. Very high mortality rates occurred at this site in 1997 and 1998, and results from these two years have not been included in the following analysis. Only batches of larvae obtained from normal embryonic development and exposed to standard rearing conditions for at least $8 \mathrm{~d}$ were considered in this study. Total duration of the larval rearing period was variable and a number of selective sieving procedures were carried out during the larval rearing period. Thus data for larval yield and growth rates were obtained on the 8th, 13 th and 17th days as well as on the last day of rearing for each larval population retaincd on suitable mesh sized sieves $(45-200 \mu \mathrm{m}$ sieves were used throughout the entire rearing period). Initial larval densities were standardized at 10 larvae $\cdot \mathrm{mL}^{-1}$, mean temperature was $23.1{ }^{\circ} \mathrm{C}$ and mean salinity was $31.4 \%$. Data were arranged into three periods: i) winter, February and March; ii) spring, April-June; iii) summer, July-September. As shown in figure 4, season had no noticeable effect on either larval yield or relative daily growth rates at day 8 for the population retained on a 71-75$\mu \mathrm{m}$ mesh. Similar analysis were performed for the entire rearing period (day 13, 17 and final day) and no seasonal differences were detected for larval size or age. As season did not appear to affect oyster larval development, data generated for all larval batches were pooled and means were calculated for relative larval yields (table $I$ ) and daily growth rates (table $I I$ ) at days $8,13,17$ and the final day.

Data presented in table I show a $30-40 \%$ decrease in total number of larvae during the first week of rearing (day 8). To understand the significance of mortality or elimination of larvae due to poor growth, data obtained for three batches of larvae in June-July 1995 were considered. In these experiments, because of the needs of the European Project GENEPHYS, no selective grading was carried out and all larvae were retained on a $45-\mu \mathrm{m}$ sieve throughout the rearing period. Larval mortality in these experiments was only $15 \%$ during this first week. If these data are extrapo- 
a)

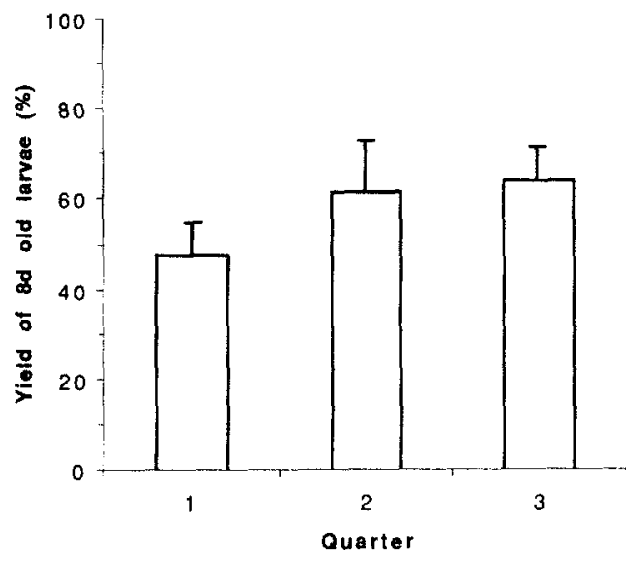

b)

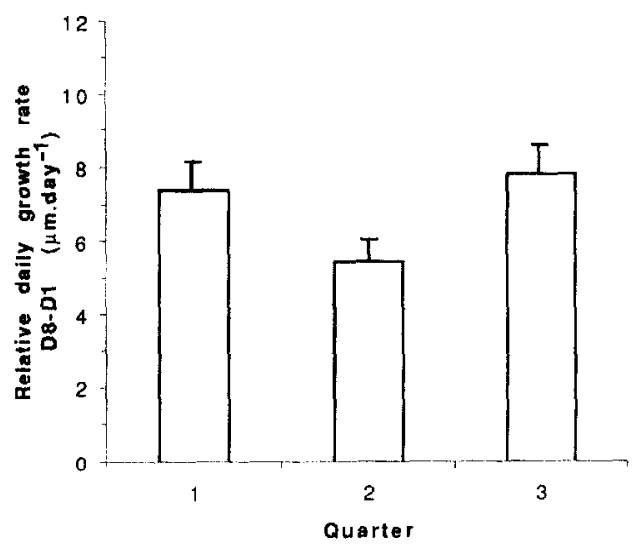

Figure 4. (a) Mean yields ( \pm standard deviation) of Pacific oyster, Crassostrea gigas, larvae on day 8 during the rearing period at the La-Tremblade hatchery. Data from 1992 to 1996 were pooled and divided into quarter periods: 1, winter (February-March); 2, spring (April-June); and 3, summer (July-September). Larvae were retained on 71-75- $\mu \mathrm{m}$ sieves. (b) Mean daily growth rates ( \pm standard deviations) of Pacific oyster, Crassostrea gigas, larvae reared at the LaTremblade hatchery. Data were collected on day 8 and correspond to the same data set shown in (a).

lated for all larval batches, it shows that $15-25 \%$ of the larval population underwent only limited development during the first week of rearing and was thus removed by selective sieving. During this same period, larval growth rates were low, in the order of 5$7 \mu \mathrm{m} \cdot$ day $^{-1}$ (table II). By day $13,60 \%$ of the population had been removed (table $I$ ) of which $40 \%$ were dead (extrapolated data, see above). Larval growth rate increased and was $8-9 \mu \mathrm{m} \cdot$ day $^{-1}$ between day 1 and day 13 (table II). This increased growth rate, which began on day 8 , is easily seen if one examines growth rates between day 8 and 13 where they are in the order of $12-13 \mu \mathrm{m} \cdot \mathrm{day}^{-1}$. This shows that growth rates doubled in the second week compared to the first week. On day 17, larval yields were between 25 and $35 \%$ and hence, had decreased very little (table I). Similarly, larval mortality at this time was constant $(40 \%$, extrapolated data, see above) which means that only $3 \%$ of the larvae died between weeks 2 and 3 . Growth rates were 8-12 $\mu \mathrm{m} \cdot$ day $^{-1}$ from day 1-17 again with a substantial increase at the beginning of the third week (12-20 $\mu \mathrm{m} \cdot$ day $^{-1}$, table II). Final results show that less than $20 \%$ of the larval population were capable of metamorphosis (table I) since only those larvae remaining on a $230-\mu \mathrm{m}$ sieve were of suitable size $(\geq 320 \mu \mathrm{m})$. A decrease in growth rates was seen at the end of the third week (from day 17 to the last day of rearing) with values of $9-10 \mu \mathrm{m} \cdot \mathrm{day}^{-1}$ (table II), a value which was similar to the mean for the entire rearing period (day 1 to last day).

\section{METAMORPHOSIS AND SPAT DEVELOPMENT}

Morphologically, the final phase of larval life is characterized by the appearance of the foot and the larvae are then called pediveligers. An eyespot becomes evident on one and subsequently on both valves of the oyster; the eyespot is less evident in scallops. A double ring appears on the shell which corresponds to a peripheral groove on which the future post-larval shell will become attached [13]. This characteristic is clearly seen in $P$. maximus and has been used to assess the capability to undergo metamorphosis. For C. gigas, this capability is based on the proportion of larvae with eyespots.

In the scallop, a correlation exists between final larval length after being sieved on a $150-\mu \mathrm{m}$ screen and the proportionof individuals possessing a double ring $(r=0.46$ and $P=0.0006)$ but the linear relationship is weak (figure S): $\mathrm{y}=1.02 \mathrm{x}-199.81$ and $r^{2}=0.21$.

A positive relationship existed between the occurrence of a double ring and the percentage of larvae which underwent metamorphosis after both the first

Table I. Mean larval yields expressed in \% (standard error) of Pacific oysters, Crassostrea gigas, as a function of time (d) and sieve mesh size for pooled data from 1992 to 1996, at the experimental hatchery in La-Tremblade. Data in bold indicate a sufficient number of replicates were available.

\begin{tabular}{|c|c|c|c|c|c|c|c|c|}
\hline \multirow{2}{*}{$\begin{array}{l}\text { Time } \\
\text { (d) }\end{array}$} & \multicolumn{8}{|c|}{ Sieve mesh $(\mu \mathrm{m})$} \\
\hline & 45 & 60 & $71-75$ & 7185 & 100112 & 125 & 150 & $180-200$ \\
\hline 8 & $84.5(8.1)$ & $71.8(5.4)$ & $58.1(4.9)$ & & 27.7 & & & \\
\hline 13 & $62.5(13.1)$ & & & $38.0(4.5)$ & $39.7(5.3)$ & $26.6(6.9)$ & & \\
\hline 17 & $59.6(13.2)$ & & & $25.8(7.3)$ & $32.9(5.5)$ & $25.4(5.0)$ & $33.5(4.8)$ & $16.0(2.0)$ \\
\hline $\begin{array}{l}\text { Last day } \\
\text { of rearing }\end{array}$ & & & & 33.8 & & $34.2(7.5)$ & $24.4(5.6)$ & $18.3(3.3)$ \\
\hline
\end{tabular}


Table II. Mean dajly larval growth rates expressed in $\mu \mathrm{m}$ (standard error) of Pacific oysters, Crassostrea gigas, as a function of time and mesh size for pooled data from 1992 to 1996 at the experimental hatchery in La-Tremblade. Data in bold indicate a sufficient number of replicates were available.

\begin{tabular}{|c|c|c|c|c|c|c|c|c|}
\hline \multirow{2}{*}{$\begin{array}{l}\text { Time } \\
\text { (d) }\end{array}$} & \multicolumn{8}{|c|}{ Sieve mesh $(\mu \mathrm{m})$} \\
\hline & 45 & 60 & $71-75$ & $71-85$ & $100-112$ & 125 & 150 & $180-200$ \\
\hline $1-8$ & $5.4(0.7)$ & $5.1(0.4)$ & $7.0(0.5)$ & & & & & \\
\hline $1-13$ & $9.8(0.2)$ & & & $8.1(0.5)$ & $9.3(1.0)$ & $12.6(1.0)$ & & \\
\hline $8-13$ & $15.3(0.5)$ & & & $12.5(1.1)$ & $13.3(1.9)$ & $18.0(1.9)$ & & \\
\hline $1-17$ & $12.5(0.4)$ & & & $12.3(0.4)$ & $8.5(0.9)$ & $10.5(0.9)$ & $11.5(1.6)$ & $14.3(0.7)$ \\
\hline $13-17$ & $20.0(1.6)$ & & & $22.3(2.1)$ & $12.5(1.4)$ & $14.4(2.0)$ & $14.7(3.0)$ & $17.2(1.0)$ \\
\hline 1 st day-last day & & & & & & $8.7(0.3)$ & $9.4(0.8)$ & $10.0(0.7)$ \\
\hline 17th-last day & & & & & & $11.0(3.5)$ & $9.0(1.8)$ & $9.0(1.0)$ \\
\hline
\end{tabular}

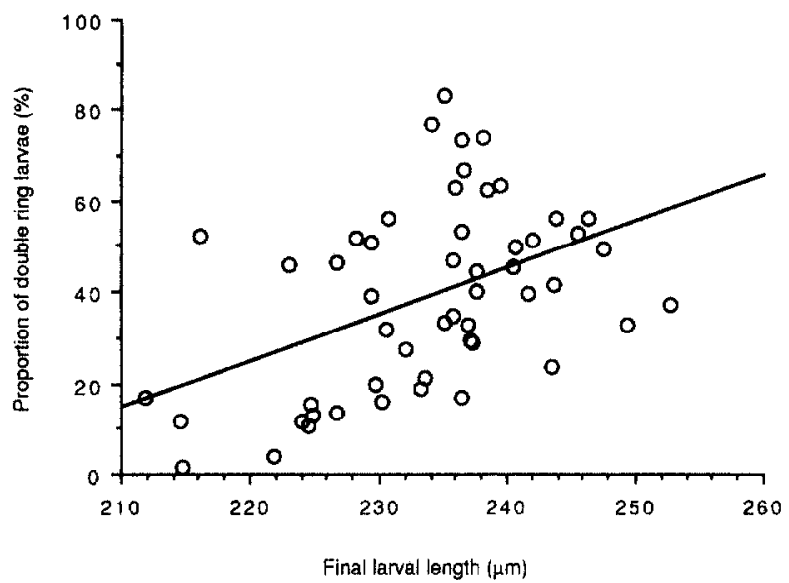

Figure 5. Relationship between mean final length and proportion of double rings in Pecten maximus larvae after collection on a $150-\mu \mathrm{m}$ sieve. Larvae were raised at the Argenton hatchery using standard techniques. Data were collected from 1992 to 1997 and pooled.

week $(r=0.67$ and $P<0.0001)$ and second week $(r=0.56$ and $P=0.005)$ of post-larval life. The linear relationship $(y=0.42 x+4.28)$ only accounted for $45 \%$ of metamorphosis levels during the first week $\left(r^{2}=0.44\right.$; figure 6$)$ and $30 \%$ during the second week. Hence, the presence of a double ring is a reliable but not a conclusive criterion to assess the capability of metamorphosis since it only accounted for about $45 \%$ of this phenomenon. Work is currently in progress in our laboratory on the effects of other physical and nutritional factors on metamorphosis and post-larval development (water flow-rates, temperature, quantity and quality of phytoplankton).

Metamorphosis in P. maximus, as characterized by the presence of the dissoconch shell, is a slow process and an increase in the number of spat was only observed 2 to 3 weeks after metamorphosis with yields of between 30 and $60 \%$. This situation can last as long as one month. Growth rate of spat is also relatively slow, in the order of 30 to $80 \mu \mathrm{m} \cdot \mathrm{day}^{-1}$. Spat reach a mean size of $2 \mathrm{~mm}$ after one to two months at which time they can be transferred to the natural environment.

A similar analysis was not undertaken for $C$. gigas, since metamorphosis in this species does not appear to

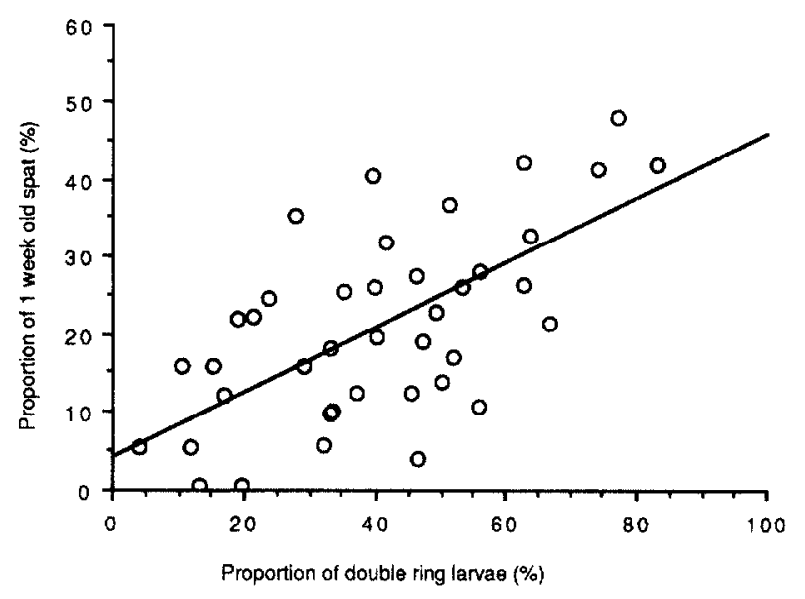

Figure 6. Relationship between percentage of double rings and percentage of metamorphosis of Pecten maximus larvae collected on a 150- $\mu \mathrm{m}$ sieve. Larvae were raised at the Argenton hatchery using standard techniques. Data were collected from 1992 to 1997 and pooled.

have any inherent difficulties, but studies have been undertaken that deal with genetic aspects of this species [5]. Metamorphosis (presence of the dissoconch shell) occurs more quickly and lasts only one or two weeks. Spat (post-metamorphic larvae) growth rates are also higher. Growth of spat in experiments carried out at the Argenton hatchery (flow-through system) during the spring ranged from $60-90 \mu \mathrm{m} \cdot \mathrm{day}^{-1}$ for spat attached to shell chips and from 130-160 $\mu \mathrm{m} \cdot \mathrm{day}^{-1}$ for spat attached to the walls of the downwelling cylinders after a rearing period of 4 to 6 weeks. Much higher growth rates $\left(400\right.$ to $\left.600 \mu \mathrm{m} \cdot \mathrm{day}^{-1}\right)$ were recorded for spat attached to spat collectors maintained in a vertical position in closed systems containing enriched seawater [5], but this latter technique is not practical at the industrial level.

Unlike the American market, French oyster farmers require single oyster spat from hatcheries since it is more easily handled. At present, the technique used to obtain such spat consists in using shell chips smaller than $400 \mu \mathrm{m}$ thus permitting settlement of only one spat per fragment.

In $P$. maximus, no settlement substrate is used. The 125- $\mu \mathrm{m}$ mesh screen fitted to the base of the downwelling cylinder is suitable for newly settled scallop 
spat which are easily removed using a paint brush (temporary attachment).

Use of chemicals to induce metamorphosis has been advocated by a number of authors [6]. Epinephrine in particular is capable of inducing and synchronizing metamorphosis by inhibiting settlement. This catecholamine has little effect on metamorphosis of the great scallop but its effects on the Pacific oyster $C$. gigas was significant [24] (figure 7). Results with oysters were obtained in a closed system and were not reproducible in a flow-through system [24]. Water turbulence appears to inhibit the action of epinephrine but such turbulence is necessary to initiate metamorphosis in P. maximus [23]. Further research is needed to determine the exact effects of these chemical and other physical parameters on stimulating metamorphosis before they will become widely accepted by the commercial industry. Improvements in the synchronization of metamorphosis and production of single spat are urgently needed at the commercial level. The present method of inducing metamorphosis and producing spat for both oysters and scallops uses a flow-through system. Animals are placed at a low density (1-5 larvae $\cdot \mathrm{mL}^{-1}$ ) on mesh at the bottom of cylinders thus al lowing water circulation and partial removal of waste products. Frequent cleaning is required to avoid plugging of the sieves. Mesh size of the bottom is changed regularly during the spat rearing period. Phytoplankton enriched water is supplied in a continuous manner whether the container is an upweller or a downweller. Major drawbacks of this technique are the large surface area required and high labour costs incurred to keep the cylinders cleaned. A new technique developed at an English hatchery circumvents some of these problems by using $100-\mathrm{L}$ cylindrical vats. Dead larvae and spat are removed from these tanks because of their

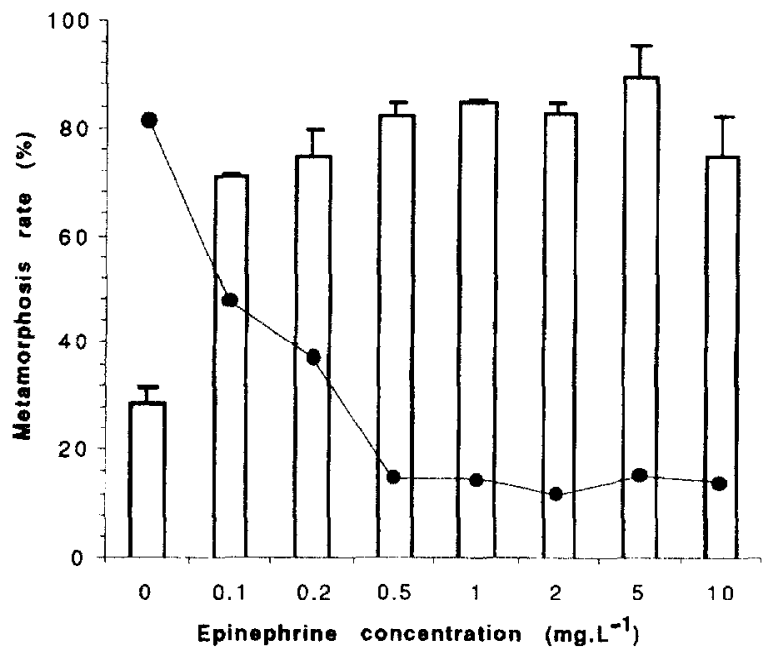

Figure 7. Effect of increasing epinephrine concentrations on meta morphosis of Crassotrea gigas expressed as the total number $(\%$ : mean \pm standard deviation) of spat formed (bar) and the number of relative rate $(\%)$ of altached post-larvae (line). low density. They are sucked up by a bell which is located at an appropriate height within the water column. Input of water and food is continuous. This hatchery uses epinephrine to induce metamorphosis and the spat are reared in vertical tanks (vats) which results in a significant reduction in space requirement.

\section{PHYTOPLANKTON PRODUCTION}

The main food used in bivalve hatcheries and nurseries is microalgae. Adequate quantities of high-quality food must be available at all times for successfull operations [3]. However, the nutritional requirements of the food can be different from both a quantitative and qualitative aspect depending on whether it is used for conditioning broodstock, rearing larvae or feeding spat.

Larval stages require only small quantities of microalgae but it must be of high microbiological and nutritional quality.

Spat require food of less high quality than larvae but certain elements such as PUFAs and/or sterols are essential in the diet [34]. Quantities of food required are high and proportional to the number and size of the spat being reared.

Broodstock requires large quantities of food when being conditioned but generally the number of animals being conditioned is relatively small. Recent studies show that certain nutritional qualities are necessary to ensure proper gametogenesis [28].

Mass production of living microalgae is a major constraint in hatcheries and nurseries both quantitalively and qualitatively. Some of these constraints are shown in table III.

Once oyster spat measure $1.5 \mathrm{~mm}$, they are usually grown in outdoor nurseries. Daily consumption in these tanks is even greater than in outdoor tanks, reaching $40-100 \mathrm{~m}^{3}$ of large scale algal culture (mean density or density equivalent to $10^{6} \mathrm{cells} \cdot \mathrm{mL}^{-1}$ ) for one million individual 6-12 $\mathrm{mm}$ juveniles [2].

An indication of the amount of algae required in commercial hatcheries is seen from microalgae production at the Coast Seafoods Company, one of the largest American hatcheries of the west coast of the USA, which produces about 20 billion eyed Pacific

Table III. Phytoplanktonic requirements for the different life stages of Crassostrea gigas and Pecten maximus in a hatchery. Volume of algae refers to Isochrysis equivalents at $8 \cdot 10^{6}$ cell $\cdot \mathrm{mL}^{-1}$.

\begin{tabular}{llll}
\hline Algae & $\begin{array}{l}\text { One breeding } \\
\text { individual }\end{array}$ & $10^{6}$ larvae & $\begin{array}{l}10^{6} \text { Post-larvae } \\
0.2-3.0 \mathrm{~mm}\end{array}$ \\
\hline Daily consumption & $0.5-1 \mathrm{~L}$ & $24 \mathrm{~L}$ & $10-20 \mathrm{~L}$ \\
Multispecific mixture & ++ & +++ & + \\
Microbiological quality + & +++ & ++ \\
Rearing period per batch $1-3$ months & $\begin{array}{l}++5-1 \\
\text { month 2-3 months }\end{array}$ \\
\hline
\end{tabular}

+ Weak requirements; ++ , medium requirements; +++ , high requirements. 
oyster larvae per year. It produces $100 \mathrm{~m}^{3} \cdot$ day $^{-1}$ of phytoplankton $\left(4 \cdot 10^{6}\right.$ cells $\cdot \mathrm{mL}^{-1}$ in $20-\mathrm{m}^{3}$ tanks) [10].

The second constraint is qualitative both biochemically and bacteriologically.

Larval and spat development is highly correlated with use of multispecific diets [26]. Each microalga species has distinct biochemical characteristics, in particular their polyunsaturated fatty acids (fatty acids made up of 20 and 22 carbon atoms and containing more than three double bonds), sterols and, to a lesser extent, vitamin content [26]. The biochemical composition of microalgae also varies with the culture medium used, age of the culture and physical parameters (e.g. temperature, light intensity, $\mathrm{CO}_{2}$ levels). In batch culture, the quality of the algae changes over time and, as a result, the biochemical content of the food provided cannot be guaranteed. As cultures are rarely, if ever, axenic, the same is true with age of the culture and can lead to a risk of causing larval disease.

At present, the standard algal culture method is batch culture with complete utilization of the biomass within one or two days. Despite improvements in culture technology, the cost of intensive microalgal culture remains high and represents $30-40 \%$ of the operation costs of a hatchery; $50 \%$ of this cost is due to labour. A further problem is that this culture technique requires a large surface area (tanks of 0.5 to $20 \mathrm{~m}^{3}$ ). Another factor is the biochemical and bacteriological quality of the cultured algae can be variable.

Because of these constraints, two other techniques have been tried to produce suitable food for bivalve larvae, spat and broodstock.

The first method consisted of attempts to find other food sources. Yeast, bacteria, soluble powders rich in vitamins or docosahexaenoic acid, dried algae, algal pastes and microcapsules have been tested experimentally but none has produced growth rates in larvae or spat that are higher or even equal to that when fed fresh microalgae. At present, it appears that dried microalgae and algal pastes are the most promising substitute foods, particularly for juveniles [27].
The second technique is development of a continuous phytoplankton culture system. This would substantially reduce costs by decreasing time spent culturing phytoplankton and would also improve overall biomass quality by providing a more constant biochemical content. It would also reduce bacterial contamination levels which can be detrimental to bivalve larvae. Although several attempts have been made to develop such a system [30], a workable model has been developed only recently at an English hatchery. The method is quite simple. A series of transparent $0.5-\mathrm{m}^{3}$ plastic bags are used, equipped with an overflow-system and a continuous input which brings nutrient enriched sterile seawater to the bags. Each bag has a production of 50-100 L $\cdot$ day $^{-1}$ of microalgae with a mean concentration of $4.10^{6}$ cells $\cdot \mathrm{mL}^{-1}$. A drawback of this system is a low production compared to lamellar or tubular devices [21, 29]. Development of a continuous phytoplankton culture system that has a high yield is one of the most promising methods for decreasing hatchery costs and increasing reliability of production.

\section{CONCLUSION}

Compared to the great scallop, the Pacific oyster has higher D larva yields $(60 \%$ for C. gigas vs. $30 \%$ for $P$. maximus) and a faster larval growth rate $\left(10 \mu \mathrm{m} \cdot \mathrm{day}^{-1}\right.$ for $C$. gigas vs. $5 \mu \mathrm{m} \cdot \mathrm{day}^{-}{ }^{-}$for $P$. muxi$m u s)$. However, Pacific oysters have a greater heterogeneity during larval development and higher mortality rates ( $40 \%$ for $C$. gigas vs. $25 \%$ for $P$. maximus) which produce lower overall yields of pediveliger larvae ready-to-set for Pacific oysters (15\%) compared to the great scallop ( $30 \%$ ).

For both species, development of continuous larval and post-larval culture methods along with development of continuous phytoplankton technology offers one of the most promising methods to improve molluscan hatchery techniques.

\section{Acknowledgements}

The authors would like to thank Dr N. Bourne for reviewing this manuscript and making very helpful suggestions.

\section{REFERENCES}

[1] Allen S.K., Bushek D., Large-scale production of triploid oysters Crassostrea virginica (Gmelin) using 'stripped' gametes, Aquaculture 103 (1992) 241-251.

[2] Bacher C., Baud J.P., Intensive rearing of juvenile oysters Crassostrea gigas in an upwelling system: optimi-

Aquat. Living Resour. 12 (2) (1999) zation of biological production, Aquat. Living Resour. 5 (1992) 89-98.

[3] Bourne N., Hodgson C.A., Whyte J.N.C., A manual for scallop culture in British Columbia, Can. Techn. Rep. Fish. Aquat. Sci. 1694, 1989, 215 p.

[4] Breese W.P., Malouf R.E., Hatchery manual for the Pacific oyster, Sea Grant Program Publ. No. ORESU.H 
75-002, Oregon State Univ., Corvallis, Oregon, USA, 1975, $22 \mathrm{p}$.

[5] Collet B., Boudry P., Thébault A., Heurtebise S., Morand B., Gérard A., Relationship between pre- and post-settlement growth in the Pacific oyster Crassostrea gigas (Thunberg), Aquaculture (1999) (in press).

[6] Coon S.L., Bonar D.B., Weiner R.M., Chemical production of cultchless oyster spat using epinephrine and norepinephrine, Aquaculture 58 ( 1986) 255-262.

[7] Dao J.C., Buestel D., Gérard A., Halary C., Cochard J.C., Le programme de repeuplement de coquille Saint Jacques (Pecten maximus L.) en France : finalité, résultats et perspectives, Coll. fr-japon. Oceanogr., Marseille 16-21 Sept., 1985, pp. 67-82.

[8] Dao J.C., Barret J., Devauchelle N., Fleury P.G., Robert R., Rearing of scallops (Pecten maximus) in France, from hatchery to intermediate culture, results of a 10 years programme (1983-1993), in: Gajardo G., Coutteau P. (Eds.), Proc. Workshop on Fish and Mollusc Larviculture, Improvement of the Commercial Production of Marine Aquaculture Species, Impresora Creces, Santiago, Chile, 1996, pp. 121-134.

[9] Devauchelle N., Minguant C., Review of the reproductive physiology of the scallop, Pecten maximus applicable to intensive aquaculture, Aquat. Living Resour. 4 (1991) 41-51.

[10] Donaldson J., Commercial production of microalgae at Coast Oyster Company; Rotifer and microalgae culture systems, Proc. US-Asia Workshop, Honolulu, HI, 1991, pp. 229-236.

[11] Dupuy J.L., Windsor N.T., Sutton C.E., Manual for design and operation of an oyster seed hatchery for the American oyster Crassostrea virginica, Spec. Rep. No. 142, Virginia Inst. Mar. Sci., Gloucester Point VA, 1997, $104 \mathrm{p}$.

[12] Faure C., Devauchelle N., Dorange G., La densité, un critère de qualité applicable en écloserie aux embryons de Pecten maximus (Mollusque Bivalve), Ifremer, Actes Coll. 14, 1992, pp. 21-30.

[13] Gérard A., Salaün M., Tritar S., Critère de compétence des larves à la métamorphose chez Pecten maximus, Haliotis 19 (1989) 373-380.

[14] Gruffydd L.L., Beaumont R.A., A method for rearing Pecten maximus in the laboratory, Mar. Biol. 154 (1982) $350-355$.

[15] His E., Robert R., Impact des facteurs anthropiques sur le recrutement de l'huître. L'exemple du bassin d'Arcachon, Oceanis 13 (1987) 317-335.

[16] His E., Seaman M.N.L., Effects of tempory starvation on the survival and on subsequent feeding and growth of oyster (Crassostrea gigas) larvae, Mar. Biol. 114 (1992) $277-279$.

[17] Le Pennec M., Gucguen F., Cochard J.C., Paulet Y.M., Dorange G., Relations entre le contenu lipidique des ovocytes de Pecten maximus (Mollusque Bivalve) et les performances des larves en élevage, Haliotis 10 (1990) $101-113$.

[18] Le Pennec M., Robert R., Avendaño M., The importance of gonadal development on larval production in Pectinids, J. Shellfish Res. 17 (1998) 97-101

[19] Loosanoff V.L., Davis H.C., Rearing of bivalve molluscs, in: Russel F.C. (Ed.), Advances in Marine Biology, Academic Press, New York, 1963, $136 \mathrm{p}$.
[20] Mann R., Some biochemical and physiological aspects of growth and gametogenesis in Crassostrea gigas and Ostrea edulis grown at sustained elevated temperatures, J. Mar. Biol. Assoc. UK 59 (1979) 95-110.

[21] Muller-Feuga A., Le Guédes R., Hervé A., Durand P., Comparison of artificial light photobioreactors and other production systems using Porphyridium cruentum, J. Appl. Phycol. 10 (1998) 83-90.

[22] Muranaka M.S., Lannan J.E., Broodstock management of Crassostrea gigas: environmental influences on broodstock conditioning, Aquaculture 39 (1984) 217-228.

[23] Nicolas L., Robert R., Chevolot L., Effect of epinephrine and seawater turbulence on the great scallop metamorphosis, Aquac. Int. 4 (1996) 293-297.

[24] Nicolas L., Robert R., Chevolot L., Comparative effects of inducers on metamorphosis of the Japanese oyster Crassostrea gigas and the great scallop Pecten maximus, Biofouling 12 (1997) 189-203.

[25] Robert R., Visite de trois écloseries industrielles de mollusques bivalves dans l'état de Washington (E.U.) et en Colombie Britannique (Canada). Rôle et importance, Équinoxe 50 (1994) 19-31.

[26] Robert R., Trintignac P., Microalgues et nutrition larvaire en écloseric de mollusques, Haliotis 26 (1997) $1-13$.

[27] Robert R., Trintignac P., Substitutes for live microalgae in mariculture, Aquat. Living Resour. 10 (1997) 315 327.

[28] Soudant P., Marty Y., Moal J., Quéré C., Le Coz J.R.. Robert R., Samain J.F., Effect of food fatty acid and sterol quality on Pecten maximus female gonad composition and reproduction process, Aquaculture 143 (1996) 361-378.

[29] Tredici M.R., Materassi R., From open ponds to vertical alveolar panels: the Italian experience in the development of reactors for the mass cultivation of phototrophic microorganisms, J. Appl. Phycol. 4 (1992) 221-231.

[30] Ukeles R., Views on bivalve larvae nutrition, in: Price D.K.S., Shaw Jr W.N., Danberg K.S. (Eds.), Proc. Ist Int. Conf. Aquaculture Nutr. Univ. Delaware, Newark, 1975, pp. 127-162.

[31] Utting S.D., Spencer B.E., The hatchery culture of bivalve mollusc larvae and juveniles, Lab. Leafl., MAFF Fish. Res., Lowestoft, 68, 1991, pp. 1-31.

[32] Walne P.R., Culture of bivalve molluscs, 50 years experience at Conwy, Fishing News Book, 1974, 189 p.

[33] Widowati I., Cochard J.C., Dorange G., Le Pennec M., Étude expérimentale de la maturation ovocytaire chez Pecten maximus et Crassostrea gigas (Mollusca Bivalvia), in: Aspects récents de la biologie des mollusques, Ifremer, Actes Coll. 13, 1992, pp. 47-56.

[34] Wikfors G.H., Patterson G.W., Ghosh P., Lewin R.A., Smith B.C., Alix J.H., Growth of post-set oysters Crassostrea virginica on high-lipid strains of algal flagellates Tetraselmis spp., Aquaculture 143 (1996) $41 \mathrm{I}-419$.

[35] Williams P., Techniques for the hatchery production of scallop Pecten maximus, in: Gajardo G., Coutteau P. (Eds.), Proc. Workshop on Fish and Molluse Larviculture, Improvement of the Commercial Production of Marine Aquaculture Species, Impresora Creces, Santiago, Chile, 1996, pp. 105-120. 